\title{
Prevalence and therapeutic measures of postpartum uterine diseases in achai cattle at livestock research \& development station Surezai, Peshawar
}

\begin{abstract}
The study was conducted at Livestock Research \& Development Station; Surezai Peshawar. The study was designed to investigate the prevalence of postpartum uterine diseases and to find out the drug of choice to treat the same in Achai cattle. For this study total of 50 Achaiadult pregnant cows having similar physiological status were selected to documents prevalence of postpartum disease and response to different antibiotic. Fresh parturated cows were observed twice daily for postpartum uterine diseases, such as Retained placenta, acute metritis and endometritis upto one month after calving. The cows found positive for any postpartum uterine symptoms were isolated and treated with various antibiotic protocols like Gentamycin sulphate $5 \%$ and Strepto - penicillin. The incidence of retained placenta recorded was 6percent, which iscomparatively lower than other breed of cattle $(8 \%)$. The incidence of uterine prolapse recorded in the current study was $8 \%$, which is higher as compared to other breeds of cattle (1 -2\%). The incidence of endometritis in Achai cattle recorded was $4 \%$, which is much lower than other breeds of cattle. The use of Gentamycine sulphate $5 \%$ intramuscularly proved to be highly efficient for uterine prolapse however its efficacy was found low in cases of Retained Placenta and Endometritis. The intrauterine use of Penbiotic (Strepto-Penicillin $5 \mathrm{gm}$ ) proved to be more responsive in cases of retained placenta and endometritis however less responsive for prolapse cases. From the finding of the present study it was concluded that Achai is a small dairy breed of Khyber Pakhtunhwa Pakistan, having resistant to uterine diseases (Retained placenta \& Endometritis) and Strepto-Penicilline is the drug of choice for its treatment.
\end{abstract}

Keywords: achai, antibiotic, postpartum, surezai, uterine diseases

Volume 7 Issue 4 - 2018

\author{
Muhammad Sohail,' Hayaz Uddin, ${ }^{2}$ \\ Muhammad Nauman-ul-Islam, ${ }^{2}$ Imtiaz Ali \\ Shah, ' Abdur Raziq,' Inamullah Wazir,' \\ Hamza Khan' \\ 'Livestock Research and Development Station, Pakistan \\ ${ }^{2}$ Livestock and Dairy Development Department (Research \\ Wing), Pakistan
}

\author{
Correspondence: Hayaz Uddin, Directorate General \\ (Research), Livestock Research and Development Station, \\ Surezai, Pakistan, Tel +03349042456, \\ Emaildrhayaz13@yahoo.com
}

Received: November 02, 2017 | Published: July 13, 2018

\section{Introduction}

Endometritis is a major postpartum disease that affects dairy cattle productivity which isaccompanied by heavy economic losses to the farmer. ${ }^{1}$ Microbial infections are highly associated with infertility as they disrupt uterine and ovarian function. Risk factors for endometritis include dystocia, male offspring, twins, stillbirth, abortion, Retained Placenta, metritis, problems with vulval conformation and ketosis..$^{2-5}$ Endometritis is characterized by an enlarged uterus and a watery redbrown fluid to viscous off-white purulent uterine discharge, which often has a fetid odor. ${ }^{6}$ The decreased fertility is caused by negative effects in the uterus and in the ovary. Uterine diseases cause lesions in the endometrium, ${ }^{7}$ disrupt endometrial function, ${ }^{8}$ and impair embryo development. ${ }^{9}$ Genital prolapse is a major but not very common reproductive disorder in cattle and buffaloes. ${ }^{9}$ It is regarded as an emergency condition and should be managed before excessive edema, mucosal trauma, contamination and fatal hemorrhage lead to a grave prognosis. ${ }^{10}$ Although a high estrogen level is considered as a prime factor for ante partum vaginal prolapse, the exact etiology of uterine prolapse is still unclear. ${ }^{11}$ Hypocalcaemia results in myometrial fatigue and delays cervical involution, both of which could predispose to uterine prolapse. ${ }^{8}$ Forced extraction of the fetus has also been incriminated as an etiological factor. ${ }^{11}$ These diseases lead to impaired welfare and fertility, and result in economic loss. These diseases have been associated with decreased pregnancy per artificial insemination (AI), extended interval to pregnancy, increased culling, and economic losses., ${ }^{2,812}$ Achai are small-sized cattle breed found in Khyber Paktunkhwa province and are famous for its high resistant to extreme environmental conditions. The home tract of Achai cattle are district Dir, Swat, Bajaur Agency and extend on the west to adjoining parts of Afghanistan. These cows are suitable for mountainous terrain and can resist cold as well as warm climate. It has a small body and thus needs little feed. It is a dairy and light draught breed that can thrive under scarce fodder availability and can produce adequately under a hilly and sub-hilly subsistence production setup..$^{13}$ Achai is yet undocumented but well-adapted cattle breed of the Hindu Kush Mountains of northern Pakistan. ${ }^{14}$ Achai cows also have a better reproductive performance than other cattle breeds in Pakistan. ${ }^{14}$ Achai cattle have average daily milk yield $2.81 \pm 0.12$ liter, while lactation period of $263.14 \pm 24.53$ days with total lactation yield of $813.07 \pm 113.39$ liter. Achai cattle have average puberty age of648.50 \pm 54.66 days having $1.43 \pm 0.11$ services per conception with average service period of $121.40 \pm 17.74$ days and average calving interval of $461.89 \pm 36.23$ days. ${ }^{15}$

\section{Objectives}

i. To find out the prevalence of postpartum uterine diseases in Achai cattle at LR\&DS Surezai.

ii. To find out the drug of choice for the treatment of postpartum uterine diseases in Achai cattle at LR\&DS Surezai.

\section{Material and method}

The study was conducted at Livestock Research \& Development Station Surezai Peshawar to find out the prevalence of postpartum uterine diseases in Achai cattle.

\section{Selection of animals}

For the study 50 adult pregnant Achai cows at Livestock Research \& Development Station Surezai, Peshawar was selected for this experiment. The selection of animals was based on similar 
physiological status. The pregnant animals were provided proper housing and extra care during last trimester of their pregnancy. The housing was properly ventilated to prevent any discomfort to pregnant animals. The animals were properly fed and water was provided round the clock.

\section{Data collection}

Fresh parturated cows were observed for postpartum uterine diseases, such as Retained placenta, Acutemetritis and endometritis up to one month after calving. Various antibiotic protocols like Gentamycin sulphate $5 \%$ Intramuscular (IM) and Pen biotic(Streptopenicillin)flushing's and as IM were used for the treatment and its efficacy was checked and recorded. The parturated cows were observed individually for a period of one month from the date of parturition to note any abnormal reproductive conditions. The cows found positive for any postpartum uterine symptoms were isolated in individual chambers and treated with antibiotics and results were recorded.

\section{Statistical analyses}

Results were calculated by using MS Excel 2010 and analyzed descriptively using SPSS 16.0 .

\section{Results and discussion}

\section{Retained placenta}

Data revealed that the incidence of retained placenta was 06 percent which is low as compared to other breeds of cattle whereas Bellows et al. ${ }^{16}$ reported an $8 \%$ occurrence of Retained placental membranes in normal parturition which shows superior inherited factors in Achai cows. Goshen and Shpigel, ${ }^{17}$ and Konyves et al. ${ }^{18}$ have reported that retained placenta causes more than $50 \%$ of the endometritis which also supports the results of the current study that the relation of Retained placenta (RP) with Endometritis which is also 50\%. Ahmed et al. ${ }^{9}$ demonstrated that cows with RP have a higher chance of contracting uterine infections and the probable reason was that RP act as a good media for bacterial multiplication. A more recent study by Potter et al. ${ }^{19}$ found that RP is highly significant risk factor of endometritis, while Han and Kim found a high occurrence of endometritis in dairy herds following cases of RP which they further linked with increased postpartum uterine infections. Similarly, Bakena (1994) showed that RP were associated with over $90 \%$ cases of endometritis. The results of the current study ( $6 \% \mathrm{RP})$ revealed that the incidence of RP is much lower as compared to other cattle breeds showing that Achai cows may have an instinct inherited resistance to the microflora in the uterus.

\section{Uterine prolapse}

Table 1 showed the incidence of uterine prolapse in Achai cows. The incidence of prolapse recorded in the current study was much higher (08 percent). Although incidence of prolapse as high as $43 \%$ has been reported in buffaloes, ${ }^{20}$, however in cattle it is only 1 to $2 \% .^{21,22}$ The increase in incidence of prolapse in Achai might be due to insemination with superior sired breed (Jersey) semen in the current cross breeding programme.

\section{Endometritis}

Table 1 presented the incidence of Endometritis in Achai Cows. The incidence of Endometritis in Achai cattle recorded was $4 \%$, which is much lower than other breeds of cattle. Kaikini reported 8.16 $\%$ incidence of Endometritis in Hostein X Gir F1 cows, which is much higher than the current study. Moreover, Sheldon et al. ${ }^{23}$ has reported the incidence of endometritis in German Black as $17.4 \%$ which is also higher than present findings.

\section{Treatment of uterine prolapse}

The use of Gentamycine sulphate $5 \%$ intramuscularly proved to be highly efficient for uterine Prolapse however its efficacy was lowered for RP and Endometritis as evident from Table 2. The local use of Penbiotic (Strepto-penicillin $5 \mathrm{gm} /$ day) intrauterine proved to be more responsive in cases of retained placenta and Endometritis, however less responsive for prolapse cases. Moreover, the intramuscular use of Penbiotic was less effective than both (Gentamycine and streptopenicilin) treatments. The results are in line with the study of Chenault and Drillich.

Table I Incidence of postpartum uterine diseases (retained placenta, prolapsed \&endometritis)

\begin{tabular}{lllll}
\hline Parameters & Positive cases & Negative cases & Total cases & Incidence Rate (Percent) \\
\hline Retained placenta & 3 & 47 & 50 & 6 \\
Prolapsed & 4 & 46 & 50 & 8 \\
Endometritis & 2 & 47 & 50 & 4 \\
\hline
\end{tabular}

Table 2 Efficacy of different antibiotics on postpartum uterine diseases (retained placenta, prolapsed \&endometritis)

\begin{tabular}{llll}
\hline \multirow{2}{*}{ Antibiotic used } & Parameters & \\
\cline { 2 - 4 } & Retained placenta & Prolapse & Endometritis \\
\hline $\begin{array}{l}\text { Gentamycine sulphate } 5 \% \text { per kg live body } \\
\text { weight intramuscular injection }\end{array}$ & ++ & $++++*$ & $+++* *$ \\
\hline $\begin{array}{l}\text { Strepto-penicillin } 5 g m \text { per kg live body } \\
\text { weight Intra-uterine }\end{array}$ & ++++ & +++ & ++++ \\
$\begin{array}{l}\text { Strepto-penicillin } 5 g m \text { per kg live body } \\
\text { weight Intramuscular injection }\end{array}$ & ++ & $++* *$ & ++ \\
\hline
\end{tabular}




\section{Findings and recommendations}

Being one of the most important issues of the dairy animals it is important to mention that the care of pregnant animals is required to be practiced in late pregnancy. The animals must not be exposed to harsh conditions to prevent any complication after parturition. Smaller Breeds of cattle should not be inseminated with semen from heavy breeds. It has been observed that Achai are a bit resistant to the uterine diseases as compared to other cattle breeds. The recommended drug of choice for Retained placenta and Endometritis are Strepto-penicillin while for Uterine prolapse is injection Gentamycine Sulphate.

\section{Acknowledgement}

We are thankful to the Dean, College of Veterinary Science for providing the facilities for research.

\section{Conflicts of interest}

Author declares there is no conflict of interest.

\section{References}

1. Turk R, M Samardžija, G Bačić. Oxidative stress and reproductive disorders in dairy cows. In: Marek ER, editor. Dairy Cows: Nutrition, Fertility and Milk Production. Nova Science Publishers: New York; 2011. p. 57-98.

2. Galvão KN, Greco LF, Vilela JM, et al. Effect of intrauterine infusion of ceftiofur on uterine health and fertility in dairy cows. J Dairy Sci, 2009;92(4):1532-1542.

3. Dubuc J, Duffield TF, Leslie KE, et al. Risk factors for postpartum uterine diseases in dairy cows. J Dairy Sci, 2010;93(12):5764-5771.

4. Potter TJ, Guitian J, Fishwick J, et al. 2010. Risk factors for clinical endometritis in postpartum dairy cattle. Theriogenology. 2010;74(1):127-134.

5. Cheong SH, Nydam DV, Galvão KN, et al. Cow-level and herd-level risk factors for subclinical endometritis in lactating holstein cows. $J$ Dairy Sci, 2011;94(2):762-770.

6. Samad MA. Reproductive disorders in cattle of Bangladesh. Livestock Advisors.1996;11:41-45.

7. Bonnett BN, Martin SW, Gannon VPJ, et al. Endometrial biopsy in Holstein-Friesian dairy cows. III. Bacterial analysis and correlations with histological findings. Can J Vet Res. 1991;55(2):168-173.

8. Sheldon IM, Dobson H. Postpartum uterine health in cattle. Anim Reprod Sci. 2004;82-83:295-306.
9. Sarfaraz Ahmed, Mohammad S Ahmad, Muhammad Yousaf, et al. Evaluation of acute toxicity and anti-inflammatory effects of baccharoides schimperi (dc.) In experimental animals. Afr J Tradit Complement Altern Med. 2015;12(1):99-103.

10. Miesner MD, Anderson DE. Management of uterine and vaginal prolapse in the bovine. Vet Clin North Am Food Anim Pract. 2008;24(2):409-419.

11. David Noakes, Timothy Parkinson, Gary England, et al. Arthur's Veterinary Reproduction and Obstetrics, $8^{\text {th }}$ edn. Spinger: 2001.

12. Gilbert RO, ST Shin, CL Guard, H, et al. Prevalence of endometritis and its effects on reproductive performance of dairy cows. Theriogenology. 200564(9):1879-1888

13. Khan MS, Rehman Z, Khan MA, et al. Genetic resources and diversity in Pakistani cattle. Pak Vet J. 2008;28:95-102.

14. Saleem M, Rahim I, Rueff $\mathrm{H}$, et al. Effect of management on reproductive performances of the Achai cattle in the Hindukush (Northern Pakistan). Tropical Animals Health and Production, 2012;44(6):12971302.

15. Uddin Hayaz, H. Ullah. Khan, M.Ilyas Khan, R. Wali. Khan and A. Naveed 2014. Productive and reproductive performance of Achai cattle maintained at livestock research \& development station surezai peshawar, Pakistan. J Anim Health Production. 2014;22(1).

16. Bellows DS, Ott SL, Pass RA. Cost of reproductive diseases and conditions in Cattle. TheProfessional Animal Scientist. 2002;18:26-32.

17. Goshen T, Shpigel NY. Evaluation of intrauterine antibiotic treatment of clinical metritis and retained fetal membranes in dairy cows. Theriogenology. 2006 Dec;66(9):2210-2218

18. Konyves L, Szenci O, Jurkovich V, et al. Risk assessment of postpartum uterine disease and consequences of puerperal metritis for subsequent metabolic status, reproduction and milk yield in dairy cows. Acta Vet Hung. 2009 Mar;57(1):155-169.

19. Christopher J. Potter, Bosiljka Tasic, et al. The Q System: A Repressible Binary System for Transgene Expression, Lineage Tracing, and Mosaic Analysis. Cell. 2010;141(3):536-548.

20. Samad MA. Reproductive disorders in cattle of Bangladesh. Livestock Advisors. 1996;11:41-45.

21. RR Woodward, JR Quesenberry. A Study of Vaginal and Uterine Prolapse in Hereford Cattle. Journal of Animal Science. 1956;15(1):119-124.

22. Sheldon IM. The postpartum uterus. Vet Clin Food Anim. 2004;20(3):569 591.

23. Sheldon IM, GS Lewis, S LeBlanc, et al. Defining postpartum uterine disease in cattle. Theriogenology. 2006;65(8):1516-1530. 